\title{
Now and then
}

\section{Swelling, spondylitis, and spears}

\author{
GAVIN CLUNIE
}

From Mount Vernon Hospital, Northwood, Middlesex

Karimui is one of the most isolated places in the highlands of Papua New Guinea. It is the central village on a vast sparsely populated plateau of subtropical jungle stretching between the central mountain range and the southern coastal plain (Fig. 1). Karimui's inhabitants live as they've always done (Fig 2); wood, stick, or reed walled homes with roofs matted thickly with palm leaves, house families who exist together farming small subsistence crop gardens and breeding pigs, their most valuable commodity. Inaccessible by road, the area relies exclusively on light aircraft links for communi-

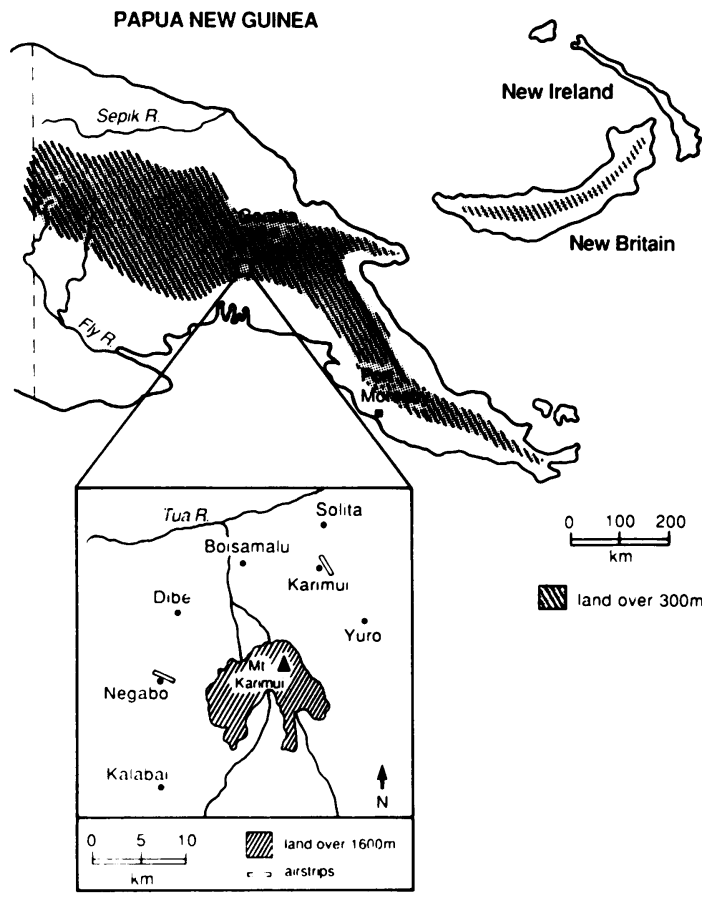

Fig. 1 Karimui plateau region, Papua New Guinea.

Accepted for publication 21 April 1989.

Correspondence to $\mathrm{Dr}$ Gavin Clunie, Mount Vernon Hospital, Rickmansworth Road, Northwood, Middlesex HA6 2RN. cation. Visiting traffic includes the occasional smat commercial or Christian mission planes and the 'spice' plane. This tiny plane ferries cardamon spiceo grown locally along with tea and coffee, to Gorokis a large provincial town $100 \mathrm{~km}$ away.

Incongruously dressed in a pair of baggy shor and clutching a large umbrella, I was left standing alone, watching as the plane bumped uncertain along into a take-off. It climbed steadily and disappeared through the cloud. Boxes filled with tinned food and syringes lay scattered about mष feet-swabs and beans, all the 'essentials' neede for a protein packed fortnight of fieldwork. A move ment on the far side of the airstrip disturbed $\mathrm{mg}$ thoughts. Abandoning the shade offered by the eaves of a small hut, a small group of men began approach me. Fortunately they were smiling.

\section{Arthritis and HLA-B27}

At the Institute of Medical Research in Gorok Kuldeep Bhatia has been working with tissue antigens for many years. He believes that in Papu New Guinea discrete frequency changes of HLA antigens may provide valuable information abou the anthropological and phylogenetic differences within the indigenous populations. Populations that between them speak about 500 different languagess and where $10 \mathrm{~km}$ between villages may represent the distance between completely separate cultures. The Karimui plateau is one place where HLA data have been gathered. HLA-B27, present in $5-14 \%$. whites, occurs in over $50 \%$ of the Pawaia, seminomadic, linguistically isolated population living in the area. In addition to providing vitgl genetic data-fuelling further anthropological research-this finding has important medical impercations in the light of some recently complete clinical work.

Since 1967, when it was first reported, physicians have failed to elucidate the cause of a distinctiog type of arthritis occurring in Papua New Guinea. \$t is consistently recorded as monoarthritis or oligearthritis confined mainly to the lower limbs apd 


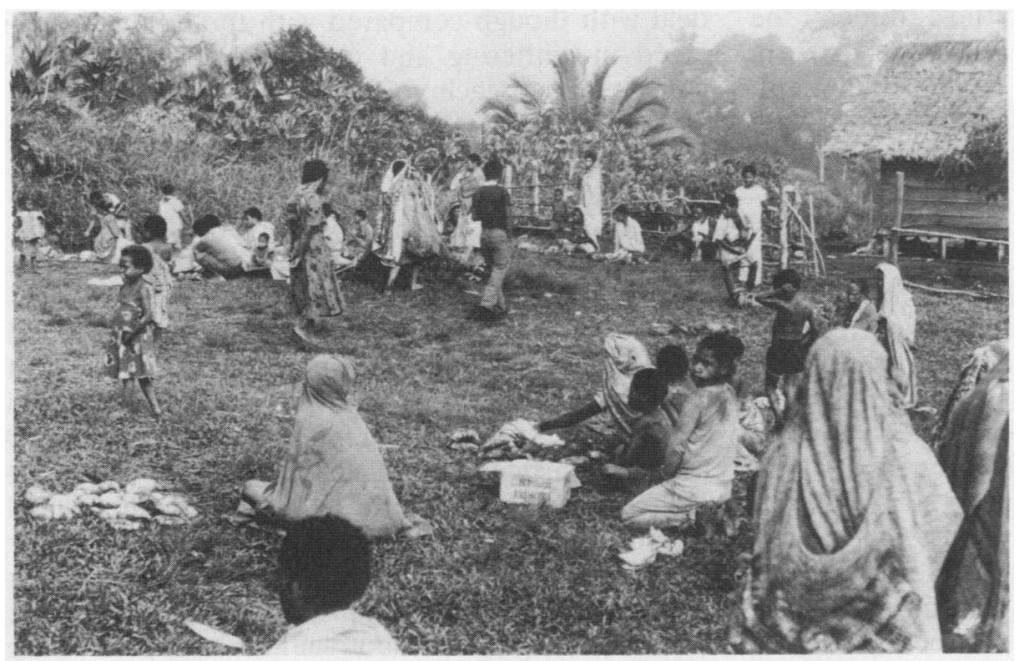

Fig. 2 Morning market in Yuro, Karimui plateau region.

occurring in young men. Reiter's disease was advocated as the diagnosis in most cases initially, though subsequently various terms for the condition, including 'tropical polyarthritis', have been used. John Richens has now shown an association between arthritis and HLA-B27 in Papua New Guinea highlanders; many patients exhibiting the features of Reiter's disease. HLA related arthritis has been studied in distinct populations elsewhere in the world, but in Papua New Guinea only hospital populations have been previously observed. We therefore planned to investigate the level and nature of arthritis and other rheumatic conditions in a discrete community such as that in Karimui, and, although logistically difficult, attempt to tissue type each study member.

In Karimui rudimentary medical services are maintained through a network of aid posts manned by vocationally trained staff: aid post orderlies. These workers are skilled at detecting and treating common conditions such as malaria, typhoid, and skin infections. Reports of aid post orderlies had indicated an appreciable level of arthritis in the area, though few records were available. It was into this uncertainty I plunged with syringes, needles, and the benefits of a crash course in rheumatology.

\section{Language}

I'd arrived at a time when aid post orderlies from outlying villages had gathered in Karimui for a conference. Puzzled by this strange coincidence, I found myself agreeing to give a small lecture that same afternoon. This was amusing not least because
I was introduced as a world expert in rheumatology but because we all spoke different languages.

Pidgin English (Tok Pisin) is a lingua franca and the national language of Papua New Guinea. It is a strange admixture of various indigenous tongues, English, and the occasional Australian expletive. Inevitably, medical vocabulary retains some characteristics and 'charms' of all these modes of communication. In Karimui two languages are spoken, Pawaian and Daribi. Recently, schools have introduced Tok Pisin as the first language despite some resistance to change. My attempts at Tok Pisin were appreciated, though I soon discovered that the spoken word was no substitute for wild enthusiastic gesticulations scattered liberally with Australian expletives.

Such a strange introduction to Karimui was a godsend as dispersing aid post orderlies were keen to inform people that I was looking for volunteers to take part in a medical study. Aided by more 'expressive' performances, this time in local market places, knowledge of my presence grew. There was an enormous response. Clinics were held each day and based in three villages. We started at 7 am and finished when the sun set, frequently with a patiently waiting group still queuing in the gloom. Although keen to see rheumatic problems, it was difficult to turn anyone away; no permanent doctor having ever been resident in the area. Problems were varied. Leprosy had been widespread in the region, though now after an extensive health programme was less prevalent. Pneumonia, sexually transmitted disease, and pelvic inflammatory disease were common but surprisingly malaria less 
so. This I assumed to be owing to the altitude of the plateau; almost $4000 \mathrm{ft}$ above sea level. My role in treating these conditions was obviously limited, however, and people considered seriously ill were referred to the provincial hospital at Kundiawa-a 40 minute flight away.

\section{Swelling}

People whom I saw with arthritis displayed unequivocably swollen joints; usually knees, usually the size of small footballs. This peripheral arthritis occurred second only to mechanical back pain in the final profile of recorded rheumatic complaints. Actually, back pain was present in $75 \%$ of the sample, and it wasn't difficult to see why-it's to do with 'bilums'. Basically an expandable string bag made from hair, wool, or twine, a bilum is used to carry anything from babies to sweet potatoes. Strung over the shoulders and supported by a loop around the forehead, bilums can hold substantial weights and as there are no pack animals in Karimui, long distances are sometimes covered with heavy, bulky loads balanced awkwardly by stooping forward. As a cause of back pain, osteoarthritis was a difficult diagnosis to make as no $x$ ray facilities were available. Because the back pain was found to be equally distributed throughout all age groups, however, and as most people do not live beyond the age of 60 , it is likely that degenerative spinal disease does not exist.

\section{Spondylitis}

One of our objectives was to assess the prevalence of ankylosing spondylitis in the community. Previous genetic studies had shown the tissue antigen HLA-B27, to be common in the local population. It is well known that there is almost $100 \%$ association between HLA-B27 and spondylitis in white populations, but no records have been made about the relationship in Papua New Guinea, though it is generally agreed that the disease is rare throughout the country.

The clinical assessment for spondylitis clearly required a detailed examination of spinal tenderness and mobility. Defining the limits of normal spinal mobility initially required some consideration as Papua New Guineans have a far greater range of movement at a joint than whites. When Schober's test is used the degree of spinal flexion at the lumbar vertebrae can easily be measured. Once its 'Papua New Guinea' normal values became familiar, the test was invaluable as there was no $x$ ray information on which to base a diagnosis of spondylitis. The clinical aspects of the study were relatively easy to deal with though compared with the difficulties we faced in gathering and processing blood samples: collected from each volunteer.

\section{Blood}

Getting a large number of the population tissue typed was always going to be a major probleme्ध Firstly, I needed the cooperation of willing volun teers and, secondly, had to ensure that all blood samples reached the laboratory within 24 hours ot collection for processing. In the face of initias scepticism in Goroka, everyone in Karimui seemed happy to participate. This I attributed to the suppoit of the aid post orderlies, many of whom has suffered with arthritis. Guaranteeing transport fơm the samples wasn't as easy. This relied on listening and detecting early the approach of the spice plane rapidly packaging the blood samples, and persuading a 'volunteer' to run with them to the airstrip-which had the chance of being some distance away. The weather occasionally prevented any flights beirfes made at all and samples were lost, left clotting in th rain on the edge of a soggy airstrip. It was therefore slightly surprising that almost 100 people were tissue typed, and much was owed to the hapless laboratore staff back in Goroka, who would frequently wor late into the night. They were thankfully philo sophical about losing their sleep.

Unfortunately the same uncertainties which face the transport of blood samples ultimately faced me्त Anxious to avoid being marooned once the rain closed in, I radioed Goroka. (Karimui has off average an annual rainfall of $5 \mathrm{~m}$, mostly falling between October and March.) The news was bade The pilot had a broken arm, the plane was being overhauled, and, on cue, it began to rain. Three days of storms left me periodically camped by thio airstrip hoping for a 'lift'. No planes came. On the fourth day, in the optimistic belief that the cloug cover was breaking up, I set up clinic under the windsock, started taking blood again, and waited. was a nervous day. At about 4 pm a sma\# commercial plane was spotted. We all jumped uf and down and were quite excited-even the mang with a needle still in his arm, although he didn exactly know why.

\section{Spears}

After such an eventful departure from Karimui and believing apathy to be the best remedy for my state of excitability, I took to wandering around the warc of Goroka Base Hospital, the major hospital servirg the highlands. Acute admissions are made surgical, medical, paediatric, and obstetric ward? 


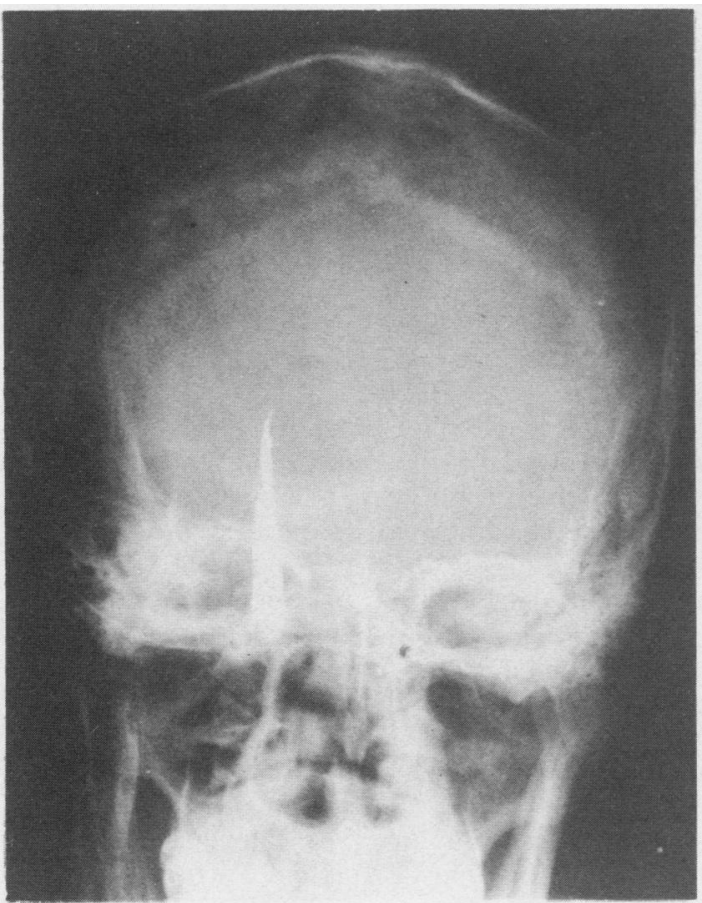

Fig. 3a

and it was here that I'd previously seen many arthritis sufferers and picked up the essentials of Tok Pisin. On a surgical ward one day I encountered a man who'd had a three month history of nonspecific headache following a tribal fight. He was conscious, alert, and not acutely ill. His skull $x$ rays were quite informative (Fig. 3). Generally, spear, axe, and arrow wounds are not an uncommon cause of hospital admission as feuding between families and clans is commonplace. Thankfully there was no

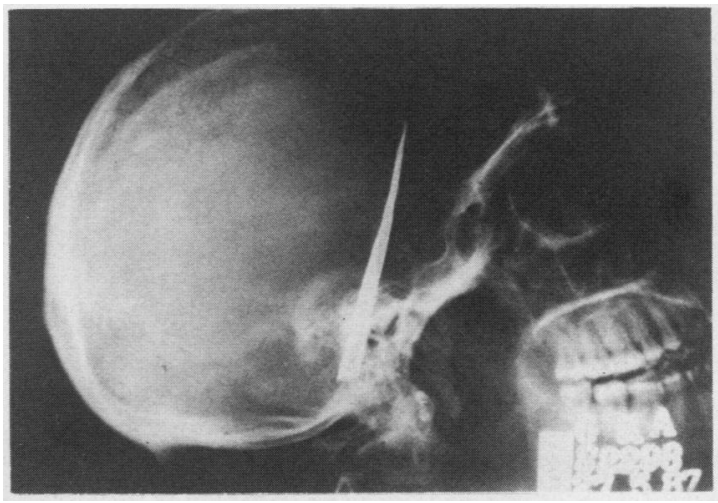

Fig. 3b

Fig. 3 (a) Anteroposterior and (b) lateral skull $x$ rays of a man with a three month history of non-specific headache.

trouble in Karimui, where the people were extremely friendly, and the only case of headache I saw was in a man who had fallen asleep under a coconut palm ...

In its isolation, Karimui remains unaffected by Western influences. The people have effectively 'travelled' the same distance in 20 years as we have in 1000 or more. The development of cardamom plantations will be of great importance to the community, all of whom own the land on which the spice is grown. Their medical needs still have to be met. A road is being planned to link the area to the rest of the highlands and this may improve health services. Such a link though would bring outsiders, drawn by the relatively rich agricultural potential of the plateau. Most people hope the road is never built and want to maintain their insularity. They are quite satisfied with the three day walk through the forest to the nearest road, even with full bilums and the substantial risk of worsening their back pain. 